\title{
Three phases of diamond growth spanning $>2.0$ Ga beneath Letlhakane established by Re-Os and Sm-Nd systematics of individual eclogitic sulphide, garnet and clinopyroxene inclusions
}

\author{
M.U. Gress ${ }^{a}$, D.G. Pearson ${ }^{b}$, S. Timmerman ${ }^{a}$, I.L. Chinn ${ }^{c}$, \\ J.M. Koornneef ${ }^{\text {a }}$, G.R. Davies ${ }^{a}$ \\ ${ }^{a}$ Vrije Universiteit, De Boelelaan 1085, 1081 HV Amsterdam, The Netherlands,m.u.gress@vu.nl, \\ suzette.timmerman@anu.edu.au,j.m.koornneef@vu.nl,g.r.davies@vu.nl \\ ${ }^{b}$ University of Alberta,EdmontonT6G 2 ${ }^{E}$, Canada,gdpearso@ualberta.ca \\ De Beers Exploration, Johannesburg, South Africa, \\ ingrid.chinn@debeersgroup.com
}

Introduction

The diamondiferous Letlhakane kimberlites are part of the Orapa kimberlite cluster $(\sim 93.1 \mathrm{Ma})$ in north-eastern Botswana, located on the edge of the Zimbabwe Craton, close to the Proterozoic Magondi Mobile Belt. Here we report the first Re-Os ages of six individual eclogitic sulphide inclusions from Letlhakane diamonds along with their carbon isotope and FTIR data from the corresponding growth zones of the host diamonds. For the first time, Re-Os data will be compared to $\mathrm{Sm}-\mathrm{Nd}$ ages of individual eclogitic silicate inclusions recovered from the same diamonds. All inclusions are considered as recording information synchronous to their corresponding diamond growth zone because at mantle temperatures $\left(>1000^{\circ} \mathrm{C}\right)$ experimental data suggests isotopic equilibration during inclusion precipitation/ recrystallization due to rapid elemental diffusion between minerals and diamond forming fluids.

\section{Analytical Results}

The analysed inclusion set encompasses pairs of individual sulphides from two diamonds (LK040, LK113) and sulphide inclusions from two separate diamonds along with their matrix composition and rhenium, osmium, iridium and platinum concentrations. Sm-Nd isochron ages at Letlhakane were obtained by compiling recently published $\mathrm{Sm}-\mathrm{Nd}$ data from nine individual eclogitic inclusions that indicate three distinct diamond forming events at $2.3 \pm 0.02,1.0 \pm 0.14$ and $0.25 \pm 0.04 \mathrm{Ga}$ (Timmerman et al., 2017) with newly acquired data e.g., two garnets of LK113. Ongoing work will analyse additional individual eclogitic inclusions for $\mathrm{Sm}-\mathrm{Nd}$ to extend the data set.

Indiviudal diamond growth zones have variable $\mathrm{C}$-isotope compositions $\left(\delta^{13} \mathrm{C}\right.$ : -38.5 to $-3.8 \%$ ), nitrogen aggregation ( 8 to $90 \% \mathrm{IaB}$ ) and nitrogen content ( 22 to $821 \mathrm{ppm} \mathrm{N}$ ) extending the range of C-isotope data compared to that previously reported on bulk stones (Deines \& Harris, 2004). Cathodoluminescence images of central plates from the sulphide-bearing samples LK040 and LK113 reveal a core-rim zonation. The two sulphides of LK040 were situated together with a cpx inclusion in the rim. The two sulphides within LK113 occured together with two garnet inclusions in the core. Individual garnet inclusions were classified by their $\mathrm{Cr}_{2} \mathrm{O}_{3}$ vs $\mathrm{CaO}$ content (Fig. 1) with categories $\mathrm{G} 4$ and G5 (e.g., LK113, LK338 lying on the $1.0 \mathrm{Ga}$ Sm-Nd isochron mentioned above) within error of the sodium threshold $\left(\mathrm{Na}_{2} \mathrm{O}>0.07 \mathrm{wt} . \%\right)$ between eclogitic, websteritic and pyroxenitic inclusions (Grütter et al. 2004).

Sulphides from the rim zone of LK040 define an 'isochron' of $0.92 \pm 0.23 \mathrm{Ga}$. Sulphides from the core zone of LK1 13 have clear imposed diamond morphology and indicate diamond formation at 0.93 $\pm 0.36 \mathrm{Ga}$ (Fig. 2). Both 'isochrons' have high, but different initial Os ratios of $1.31 \pm 0.24$ and $0.69 \pm$ 0.44, respectively. Corresponding $\mathrm{T}_{\mathrm{MA}}$ ages of the sulphides range from 1.06 to $2.3 \pm 0.1 \mathrm{Ga}$, their $\mathrm{Re}$ and Os concentrations (200-2500 ppb and 14-134 ppb, respectively) are low compared to high Os peridotitic inclusions and due to the small sample size $(3.0-35.7 \mu \mathrm{g})$, account for the relatively large errors in the ages. C1-normalized iridium and platinum compositions from the analysed sulphide inclusions display enrichment in Ir (3.4 to $33 \mathrm{ppb})$ and Pt (2.3 to $28.1 \mathrm{ppb})$ in comparison to eclogitic xenolith data from Orapa that are depleted relative to chondrite (McDonald \& Viljoen 2006). 


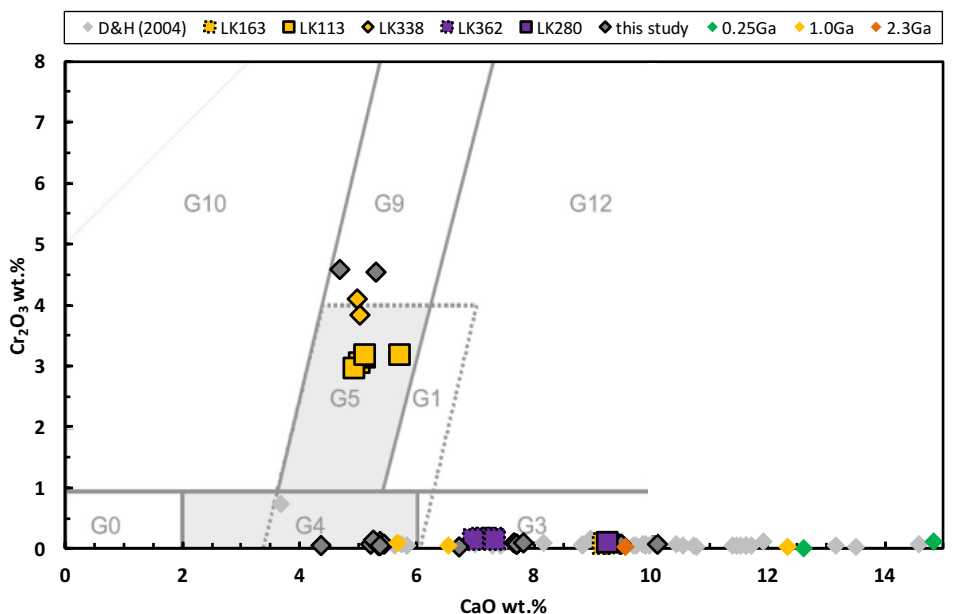

Fig. 1: Garnet classification scheme of individual inclusions from Letlhakane with categories after Grütter et al. (2004). Reference data from Deines \& Harris (2004) as grey symbols without borders; Coloured symbols without borders from inclusions on isochrons after Timmerman et al. (2017); Coloured symbols with borders from this study; Grey symbols with border not yet analysed for Sm-Nd. The inclusions plot in the fields for highand low-Ca eclogitic garnets (G3, G4); pyroxenitic, websteritic and eclogitic garnets (G5) and lherzolitic garnets (G9).

\section{Discussion}

The 2-point Re-Os isochrons are within error of previously reported ages from the adjacent $(\sim 40 \mathrm{~km})$ Orapa mine $(1.0 \mathrm{Ga})$ based on sulphide inclusions from different diamonds (Shirey et al., 2004), and compare well with a two-point isochron of individual eclogitic inclusions $(1096 \pm 230 \mathrm{Ma})$ reported by Timmerman et al. (2017) as well as with a $990 \pm 50 \mathrm{Ma}$ isochron for composite $(\mathrm{n}=730)$ eclogitic silicate inclusions by Richardson et al. (1990).

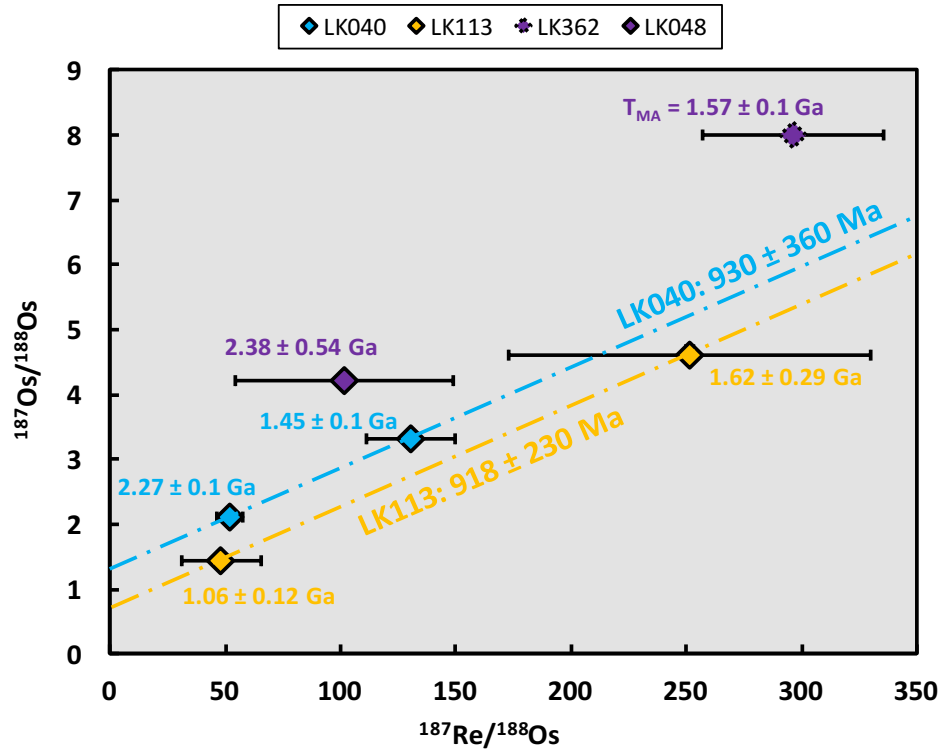

Fig. 2: Re-Os isochron data of individual eclogitic inclusions from Letlhakane (LK) with calculated mantle model ages. The two isochrons are each defined by two sulphide inclusions.
Although the sulphides of LK040 and LK113 are in the same growth zone in their host diamonds, their $\mathrm{T}_{\mathrm{MA}}$ ages (1.06 to $2.3 \pm 0.1 \mathrm{Ga}$ ) are highly variable. This highlights that using model ages in sulphides with low to medium Os contents (e.g., eclogitic sulphides) can be problematic, due to the high variability of initial Os isotope ratios. This variability indicates why it is essential, for Re-Os diamond dating, to use sulfides from the same diamond/ growth zone - clearly there is no single isochron that would fit all the sulfide data in Fig. 2.

The same problem may occur when obtaining $\mathrm{Sm}-\mathrm{Nd}$ age information from diamonds containing single or pairs of silicate inclusions (i.e., how to establish that inclusions are cogenetic). In contrast to the Re-Os

data, however, initial ratios determined for the Sm-Nd isochrons in this study (Fig. 3) are close to bulk Earth $(\varepsilon \mathrm{Nd}$ : -0.5 to +6.2$)$ and much less variable than the Re-Os system, due to smaller parentdaughter isotope fractionations and the larger decay constatnt of ${ }^{147} \mathrm{Sm}$.

Following the approach of Timmerman et al. (2017) we group inclusions from different diamonds based on a combination of the nitrogen aggregation state $(\% \mathrm{IaB})$ of the corresponding diamond growth zone and Sr-isotopes of the inclusion. Although not all these criteria have yet been applied in the present study, silicate inclusions of LK113, LK163, and LK338 fall on the $998 \pm 140 \mathrm{Ma}$ isochron of Timmermann et al (2017). A clinopyroxene of LK338 from a different growth zone and of LK079 falls on the $2.3 \mathrm{Ga}$ isochron; and the clinopyroxene of LK131 falls onto the $245 \pm 38 \mathrm{Ma}$ isochron. 
The garnet of LK280 does not plot on a previously defined isochron. The addition of garnets of LK113 and LK163 to the $1.0 \mathrm{Ga}$ isochron improves the fit and precision of the age to $1081 \pm 67 \mathrm{Ma}$. This Sm-Nd isochron age is within error of the $918 \pm 230 \mathrm{Ma}$ Re-Os isochron age of the sulphides from the same diamond. Hence a $\sim 1 \mathrm{Ga}$ diamond-forming event in the lithosphere beneath the Orapa/ Letlhakane region is firmly established and is further evidence of a more wide-spread, circa $1 \mathrm{Ga}$ diamond-forming event over the Kaapvaal craton, e.g., at Koffienfontein or Premier (Pearson et al., 1998, Richardson 1986).

The clinopyroxene of LK040 fits on both the 0.25 and $1.0 \mathrm{Ga} \mathrm{Sm}-\mathrm{Nd}$ isochron. Given the high chromium content of LK040 and clinopyroxene and garnets of LK113 and LK338, all these inclusions (including LK040) likely grew at $1.0 \mathrm{Ga}$. These preliminary data indicate that different inclusion populations (plotting in G3, G4, G5; Fig. 1) all formed at $1.0 \mathrm{Ga}$, suggesting that diamond formation occurred at the same time in different parts of the sub-continental lithospheric mantle, via metasomatic processes where carbon-bearing fluids infiltrate different host rock lithologies.

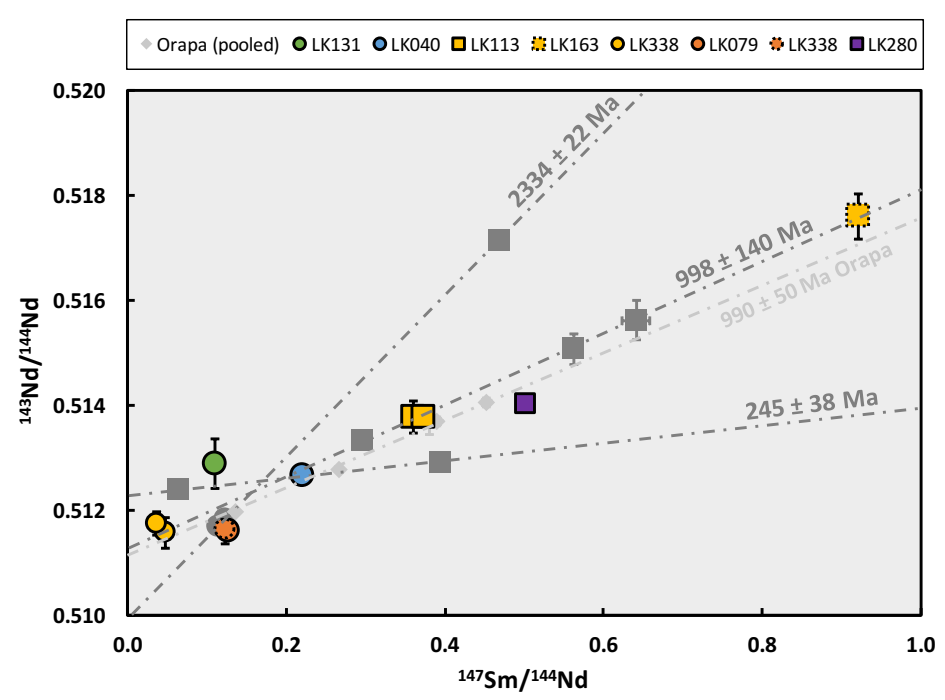

Fig. 3: Compilation of $\mathrm{Sm}-\mathrm{Nd}$ isochrons of silicate inclusions from Letlhakane (LK) and Orapa. Square markers represent individual garnets, circles individual clinopyroxene inclusions. Colour codes: dark grey symbol define isochron ages of $2334 \pm 22 \mathrm{Ma}, 998 \pm 140 \mathrm{Ma}$ and $245 \pm$ $38 \mathrm{Ma}$ for Letlhakane after Timmerman et al. (2017); Light grey symbols represent groups of pooled eclogitic inclusions $(n=720)$ from Orapa on a $990 \pm 50 \mathrm{Ma}$ isochron after Richardson et al. (1990); Coloured symbols with borders represent newly acquired data from this study.

This is the first time that both sulphide and silicate inclusions from a single growth zone in diamonds have been measured. The Re-Os and $\mathrm{Sm}-\mathrm{Nd}$ isotope systems of individual silicate and sulphide inclusions record the same time of diamond formation. The entire inclusion dataset demonstrates a phase of Neoarchean/ Paleoproterozoic diamond formation as well as Mesoproterozoic and Mesozoic diamond growth, in punctuated events spanning $>2.0 \mathrm{Ga}$.

\section{References}

Deines P, Harris JW (2004) New insights into the occurrence of $13 \mathrm{C}$-depleted carbon in the mantle from two closely associated kimberlites: Letlhakane and Orapa, Botswana Lithos 77:125-142

Grütter HS, Gurney JJ, Menzies AH, Winter F (2004) An updated classification scheme for mantlederived garnet, for use by diamond explorers Lithos 77:841-857

McDonald I, Viljoen K (2006) Platinum-group element geochemistry of mantle eclogites: a reconnaissance study of xenoliths from the Orapa kimberlite, Botswana Applied Earth Science $115: 81-93$

Pearson DG, Shirey SB, Harris JW, Carlson R (1998) A Re-Os isotope study of sulfide diamond inclusions from the Koffiefontein kimberlite, S. Africa: constraints on diamond crystallisation ages and mantle Re-Os systematics Earth Planet Sci Lett 160:311-326

Richardson SH (1986) Latter-day origin of diamonds of eclogitic paragenesis Nature 322:623-626

Richardson SH, Erlank A, Harris JW, Hart S (1990) Eclogitic diamonds of Proterozoic age from Cretaceous kimberlites Nature 346:54-56

Shirey SB, Richardson SH, Harris JW (2004) Integrated models of diamond formation and craton evolution Lithos 77:923-944

Timmerman S, Koornneef JM, Chinn IL, Davies GR (2017) Dated eclogitic diamond growth zones reveal variable recycling of crustal carbon through time Earth and Planetary Science Letters 463:178-188 